\title{
Françoise Court-Peréz, La lettre dans l'oeuvre de Gautier ou le mot de la fin
}

\section{Maria Dario}

\section{Q OpenEdition}

1 Journals

\section{Edizione digitale}

URL: https://journals.openedition.org/studifrancesi/40972

DOI: 10.4000/studifrancesi.40972

ISSN: 2421-5856

Editore

Rosenberg \& Sellier

\section{Edizione cartacea}

Data di pubblicazione: 1 juillet 2004

Paginazione: 213

ISSN: 0039-2944

\section{Notizia bibliografica digitale}

Maria Dario, «Françoise Court-Peréz, La lettre dans l'oeuvre de Gautier ou le mot de la fin», Studi Francesi [Online], 142 (XLVIII | I) | 2004, online dal 30 novembre 2015, consultato il 09 septembre 2021. URL: http://journals.openedition.org/studifrancesi/40972; DOI: https://doi.org/10.4000/studifrancesi. 40972

Questo documento è stato generato automaticamente il 9 septembre 2021.

\section{(c) 9 (i) $\Theta$}

Studi Francesi è distribuita con Licenza Creative Commons Attribuzione - Non commerciale - Non opere derivate 4.0 Internazionale. 


\section{Françoise Court-Peréz, La lettre dans l'oeuvre de Gautier ou le mot de la fin}

\section{Maria Dario}

\section{NOTIZIA}

FRANÇOISE COURT-PERÉZ, La lettre dans l'oeuvre de Gautier ou le mot de la fin, « L'Esprit créateur», n. 4, tomo XL, inverno 2000, pp. 50-57.

1 Lo studio illustra la crisi della forma epistolare nella narrativa del primo Ottocento alla luce dell'esperienza romanesca di Gautier che, pure utilizzandone le risorse inventive e gli effetti stilistici, intrattenne con essa un rapporto reticente ed ambiguo. Gravata dalla sua funzione referenziale e dominata dalle convenzioni sociali e dagli stereotipi scritturali che ne minano l'efficacia comunicativa, la lettera nel romanzo gauteriano rimanda generalmente ad un'immagine critica e ad un uso anti - letterario che la rendono un modello negativo di «scrittura artistica». 